\title{
Does Health Affect Party Identification? : Evidence from German Panel Data
}

\section{Papageorgiou, Achillefs}

2019-09-17

Papageorgiou , A , Mattila , M \& Rapeli , L 2019 , ' Does Health Affect Party Identification?

Evidence from German Panel Data ', Representation : the journal of representative democracy , vol. 55 , no. 2 , pp. 215-224 . https://doi.org/10.1080/00344893.2019.1635198

http://hdl.handle.net/10138/305531

https://doi.org/10.1080/00344893.2019.1635198

acceptedVersion

Downloaded from Helda, University of Helsinki institutional repository.

This is an electronic reprint of the original article.

This reprint may differ from the original in pagination and typographic detail.

Please cite the original version. 


\title{
Does Health Affect Party Identification? Evidence
}

\author{
from German Panel Data
}

\author{
Achillefs Papageorgiou (Åbo Akademi University) \\ Mikko Mattila (University of Helsinki) \\ Lauri Rapeli (Åbo Akademi University)
}

\begin{abstract}
Recent research has shown the effect of health on voter turnout, arguing that attenuated health depresses voting. However, we know little about how health is connected to the psychological factors, such as party identification, that precede actual political participation. Employing data from the German Socio-Economic Panel (SOEP), we show that when a person's health deteriorates, the degree of partisan attachment declines, whereas health improvement does not automatically restore the level of party identification to previous levels.
\end{abstract}

Keywords: party identification, health, SOEP, random and fixed effects.

Final pre-publication draft version / The Version of Record of this manuscript has been published and is available in 'Representation. Journal of Representative Democracy' (16 July 2019) https://www.tandfonline.com/doi/full/10.1080/00344893.2019.1635198 


\section{Introduction}

Recently, the issue of health has received renewed interest from scholars of political behaviour. These studies have focused on health and political participation while controlling for the effects of key socio-demographic variables (see, Mattila et al. 2017 for an overview). However, accounting for socio-demographic factors alone is not sufficient when we want to analyse the complex mechanisms behind political engagement. Since the 1950s, a psychologically oriented research tradition has, instead, concentrated on party identification as a key component in empirical analyses of democratic political behaviour (Campbell et al. 1954).

Classic definitions of party identification stress its psychological or affective nature. In 'The American Voter', party identification is defined as "an individual's affective orientation to an important group-object in his environment" (Campbell et al. 1960: 21, emphasis added), while in 'The Voter Decides' it is defined "as the sense of personal attachment which the individual feels towards the [partisan] group of his choice" (Campbell et al. 1954: 89, emphasis added). More recent research developments (e.g., Green et al. [2002]; Greene [2004]) place emphasis on the importance of the group identification that the classical definitions of party identification entail, arguing that party identifiers develop a sense of social identity akin to other social groups, such as religious or ethnic groups (Green et al. [2002]; Miller and Shanks [1996]).

We suggest that scholarship should look beyond socio-demographic factors to understand the mechanisms underlying the commonplace statement that health affects political participation. Our analysis demonstrates that party identification is, possibly, one such mechanism. We use the waves from 1984 to 2015 of the German Socio-Economic Panel (SOEP) to investigate if and how health affects party identification.

Our study contributes to the literature in two ways. First, although there is a growing body of research on the effect of health on political participation (e.g., Couture and Breux [2017]; Mattila et al. [2013]; Ojeda and Pacheco [2017]; Rapeli et al. [2018]), this is the first study to analyse the effect 
of health on party identification. This is important since studies of the effect of health on behavioural indicators capture its effect as a consequence of party identification and not on the concept itself (Burden and Klofstad 2005), that is, psychological and not behavioural. Second, research exists on the effects of social identities on health (e.g., Haslam et al. [2014], Jetten et al. [2017]); the other direction of the presumed causal relationship has received hardly any attention. We address this research lacuna by examining the effect of health on party identification.

\section{Social identities and health}

According to social identity theory, people arrange their social environment into categories in reference to the self and, as such, they classify others as belonging to the same category (in-group) or to different categories (out-group). Individuals need to be associated with a positive social identity(Tajfel and Turner 1986). To achieve this, they compare their own group with groups that they perceive to be different in a way that will always favour their in-group. In other words, intergroup comparison leads to in-group favouritism, meaning a positive evaluation of the group that one belongs to (Hogg and Abrams 1988). During this process of comparison, individuals foster their sense of social identity (Hogg and Abrams 1988).

A plethora of studies (e.g., Greene [2002, 2004]; Green et al. [2002]; Kelly [1988]; Roscoe and Christiansen [2001] etc.) have argued that social identity is a core aspect of party identification, meaning, "persons look to political parties as meaningful social reference groups with which they identify. In other words, much as one self-identifies as a Black, Hispanic, Protestant, Catholic, Puerto Rican, and so on, one may identify as a Democrat or Republican" (Green et al. 2002: 182). In this respect, scholars have shown that the core elements of social identity theory, such as the emotional significance of group membership, intergroup differentiation and in-group favouritism, also play important roles with respect to the identification with political parties. For example, party identifiers develop a psychological attachment to the political party that they identify with (Roscoe and 
Christiansen 2001), they differentiate their own political group from the supporters of other parties (Kelly 1988) and they exaggerate the positive characteristics of the party with which they identify in relation to other political parties (e.g., Greene [2002, 2004]). The fact that party identification shares many similar characteristics with other types of social identification is summarized in Greene's assertion that "the original conception of party identification in The American Voter is a precursor of social identity theory years ahead of its time" (Greene 2004: 136).

To date, studies of the relationship between health and social identity have focused on the effect of social identity on health rather than the effect of health on social identity. For example, Haslam et al. (2014) and Jetten et al. (2012) argued that social identities function as "social cures" and positively affect the health and well-being of individuals because a sense of belonging can boost self-esteem and efficacy. On the other hand, belonging to groups where social support is missing may, in turn, have detrimental effects on health (Jetten et al. 2017). The other direction of the relationship, the effect of health on social identities, although it may seem more intuitive, has received much less attention, at least from political scientists. The few existing studies only indirectly address the matter. Studying the effect of chronic illness, Leventhal et al. (1999) report cases in which patients with chronic illness revitalized their social identities within the context of their social environments, such as family or work colleagues, in an effort to sustain hope and self-esteem. According to this line of research, it is also possible that some chronic diseases, such as cancer, foster the formation of a new identity that can lead to political mobilization through membership in disease-related advocacy groups (Gollust and Rahn 2015).

\section{Party identification, political participation and health}

In political science, party identification has been linked to political participation and orientation (Krishna and Sokolova 2017). It impacts voter turnout (e.g. Bartels [2000]; Dinas [2014]), voting choice (Bonneau and Cann 2015) and protest behaviour (Finkel and Opp 1991). Goren (2005) shows 
that party identification may even shape individuals' core political values. The strength of party identification is also positively linked to age, i.e., it becomes stronger with age. According to Dinas (2014), the reason for this is the reciprocal relationship between partisanship and voting. Repeatedly voting for the same party over time may increase the feelings of partisanship, which, in turn, increase the likelihood of continuing to vote for the same party.

Likewise, health has been linked to various forms of political activity. It has been shown that health problems are linked with a decreased propensity to vote (Couture and Breux [2017]; Goerres [2007]; Mattila et al. [2013]; Ojeda and Pacheco [2017]), lower levels of political trust (Mattila and Rapeli 2018) and party choice (Rapeli et al. 2018). The effects of health on forms of political participation other than voting seem to be more varied (Ojeda [2015]; Söderlund and Rapeli [2015]).

However, we have little evidence on the mechanisms that connect health with political participation. The possible mechanisms can be divided into short and long-term effects. A temporary illness preventing a person from voting is a one-off event that has little general significance except in those rare cases where an epidemic affects large groups of people. More important are the long-term effects of chronic and/or severe illnesses and disabilities. Chronic illness may drain personal energy, which may lead a person to focus more on her immediate social surroundings, such as friends and family, than on societal matters. It may also lead to feelings of hopelessness and negative expectations for the future (Ojeda 2015), which, in turn, can decrease levels of political trust (Mattila and Rapeli 2018).

A similar reasoning can be applied to party identification. When people experience poor health, their focus in life may change and it is likely that politics may not seem to be very important in comparison with other concerns. Health problems may also lead to unemployment and lower incomes, which further exacerbate the problematic situation that a person is facing. These developments can be reflected in people's feelings towards actors in the political system. Thus, we hypothesize that poor health is associated with lower levels of party identification. 
However, we are not only interested in the correlational analysis between levels of health and party identification, rather, we want to more closely explore the possible causal relationship between these two factors. Hence, we use a difference-in-differences model to analyse how changes in health status affect party identification. We use panel data with random effect (RE) and fixed effect (FE) models to study the relationship. Although causal relations are very difficult to prove empirically, the fixed effects formulation provides a very tough test for our hypothesis.

\section{Data and research design}

Our data draws on the German Socio-Economic Panel (SOEP) (Wagner et al., 2007) that measures party identification during the period spanning 1984 to $2015^{1}$. Combining partisan attachment (yes/no) and degree of party identification ('very weak' to 'very strong' partisan attachment) the analysis generates a variable with six values: (1) 'no partisan attachment', (2) 'very weak partisan attachment', (3) 'fairly weak partisan attachment', (4) 'moderate partisan attachment', (5) 'fairly strong partisan attachment' and (6) 'very strong partisan attachment'. Health is captured with the question "How would you describe your current health?" with a scale ranging from 1 to 5 (very poor - poor - fair - good - excellent).

We use difference-in-differences (DiD) analysis to study the effect of health on party identification. Böckerman and Ilmakunnas (2009) developed a model specification that showed if unemployment affects self-assessed health. Our research note adapts this model for our research: to analyse the causal relationship between treatment (health) and outcome variables (party

\footnotetext{
${ }^{1}$ Drawing on multi-stage random samples, SOEP interviewed around 30,000 respondents each year from nearly 11,000 households. The interview methodology consists of pre-tested questionnaires. The panel is unbalanced and detailed information on attrition can be found in SOEP's relevant documentation at: https://www.diw.de/documents/publikationen/73/diw_01.c.579464.de/diw_ssp0480.pdf
} 
identification). For the purposes of the analysis, when respondents assess their health as being 'very poor', 'poor' or 'fair', health is classified as 'bad' and when respondents assess their health as being 'good' or 'excellent', health is classified as 'good'.

The model differs from simple difference-in-differences models because it is possible that a person experiences several changes in her health over the period covered by our data. For example, a person may start with good health, then become ill and then, after a period of poor health, once again regain good health. Alternatively, the development can follow a mirror image: a person may start with poor health, get better but then become sick again. To cover the possible developments we use four dummy variables:

(1) BHAG (Bad Health After Good): a dummy for those whose health is currently 'bad' after a period of 'good'. If, for example, someone's health is 'bad' at wave five and it was 'good' at wave four, the variable takes the value of one in wave five and during the following years, unless there is another change in the health condition.

(2) GHAB (Good Health After Bad): a dummy for those whose health is currently 'good' after a period of 'bad' health. This dummy equals one during all waves of 'good' health after a spell of 'bad' health.

(3) GHONCE (Good Health Once): a dummy for individuals whose health becomes 'good' (it was previously 'bad') at least once during the period of the survey. For example, if someone's health was 'bad' at wave two and became 'good' at any of the following waves, the dummy takes the value of one. This variable does not vary over time but only across individuals.

(4) BHONCE (Bad Health Once): a dummy variable for individuals whose health becomes 'bad' at least once. As in the case of GHONCE, the value of BHONCE is constant within individuals.

(5) BHALW (Bad Health Always): a dummy that indicates that the respondent's health is 'bad' throughout the panel. This dummy remains constant for the same individual across time. 
(6) Our models account for possible changes in the health of the same individual during the time in which they are included in the panel. Our general model specification is:

$$
\begin{aligned}
\text { DPID }_{i t}=\alpha+ & \beta(\text { BHAG })_{i t}+\gamma(\mathrm{GHAB})_{i t}+\zeta(\mathrm{GHONCE})_{i}+\delta(\mathrm{BHONCE})_{i}+\eta(\mathrm{BHALW})_{i} \\
& +\kappa(\mathrm{AGE})_{i t}+\lambda\left(\mathrm{AGE}^{2}\right)_{i t}+\mu(\mathrm{EDUC})_{i t}+\xi(\mathrm{WSTAT})_{i t}+\varphi(\mathrm{GENDER})_{i} \\
& +\psi(\mathrm{WAVE})_{t}+\mathrm{u}_{i}+\varepsilon_{i t}
\end{aligned}
$$

Here, DPID stands for the degree of voters' party identification and $\beta, \gamma, \delta, \zeta, \eta$ are the estimates of the main independent variables BHAG, GHAB, GHONCE, BHONCE and BHALW, respectively; $\kappa, \lambda, \mu, \xi$ are estimates for the control variables, such as 'age', 'age ${ }^{2}$ ' 'education' (EDUC) and 'working status' (WSTAT), respectively. We also include time-invariant characteristics, such as gender, and time specific effects (WAVE). Finally, $\mathrm{u}_{i}$ stands for the effects that are unobserved and are peculiar only to individual units. Thus, the model has two errors: one that varies only across individuals $\left(\mathrm{u}_{i}\right)$ and one that varies across both individuals and time $\varepsilon_{i t}$ (Allison 2009).

The reference category for the health dummies is a person who remains healthy throughout the study $(\alpha)$. The average degree of voters' party identification (DPID) for a person who always has poor health is $\alpha+\eta$. If a person starts out in good health but is now in bad health, her DPID is $\alpha+\beta+\delta$ and for a person who starts out in poor health but is currently in good health, it is $\alpha+\gamma+\zeta$. Estimates from the RE specifications are based on an assumption that the unit effects, $\mathrm{u}_{i}$, are distributed independently from all explanatory variables. To relax this assumption, we also specify a fixed effects model $^{2}$ that cancels out the unit effects by demeaning, that is, by subtracting variable values from their over-time averages. This alleviates the omitted variable bias as all time-invariant factors are automatically controlled for. Under this specification, the time-invariant health variables of GHONCE, BHONCE and BHALW drop from the equation. Thus, the only health-related variables

\footnotetext{
${ }^{2}$ Hausman tests support the use of FE instead of RE for both Model 1 and Model 2 ( $p<.0000$ in both cases).
} 
that are estimated are those indicating changes in health status, i.e., BHAG and GHAB. Political interest a fundamental variable determining political behaviour (e.g. Prior 2010) and thus likely a strong predictor of PID as well. For robustness purposes, we run analyses both with and without political interest.

\section{Results}

The results from the RE and FE models are presented in Model 1, Table 1. Model 2 checks for robustness by adding political interest. The results on the control variables show that party identification is stronger for males and for people with higher education. Further, employed persons (full-time, part-time, etc.) seem to have less time to develop strong attachments to parties compared to the unemployed, yet the effect is not significant when political interest is added to the analysis. Moreover, age has a curvilinear effect on the outcome: party identification increases up to a certain age and then declines but only under Model 1. In Model 2, which includes political interest, the estimate of age $^{2}$ is not significant. It is, therefore, important to note that the estimates of political interest are highly significant, showing that party identification increases as interest in politics increases.

\section{'Table 1 here'}

Focusing on our main independent variables, we note that BHALW (Bad Health Always) is significant and negative, showing that respondents with bad health have lower levels of party identification than others. Further, when a person's health becomes poorer, as indicated by the BHAG (Bad Health After Good) dummy, DPID decreases, as hypothesized. When a person regains her good health after a spell of poor health, that is, when the dummies for GHAB (Good Health After Bad) and (GHONCE) are equal to one, the total effect on party identification is almost zero as the estimates of GHAB (-0.03) and GHONCE (0.04) cancel each other out. This means that becoming healthy does 
not automatically mean that a person would bounce back to the same level of party identification as that prior to becoming ill.

The FE specification includes only the time variant BHAG (Bad Health After Good) and the GHAB (Good Health After Bad) health variables. BHAG is statistically significant and negative, which, in substantive terms, means that when a persons' health deteriorates her degree of partisan attachment decreases. The other health variable, GHAB, is not statistically significant in the FE models, confirming the observation of asymmetry: poor health decreases party identification while getting better does not restore the earlier levels of identification. Thus, it seems that the effect of health problems is persistent or, at least, relatively long-lasting. It is unlikely that a person restores her attachment to her favourite party to the same level after experiencing a significant illness or other major health problems.

\section{Conclusions}

Party identification is one of the main drivers of political participation and previous studies also show how health problems affect participation. However, this is the first study to analyse directly the relationship between party identification and health. This is important for two main reasons. First, the effect of health on behavioural indicators that are consequences of party identification is not always adequate for describing the effect of health on party identification itself, which is mainly psychological in nature. Second, party identifiers develop a sense of group belonging that is similar to other social groups, such as religious or ethnic groups (Green et al. [2002]; Miller and Shanks [1996]) and, therefore, our study contributes to the limited research on the effect of health on other important social identities. Using panel data, we have demonstrated support for the hypothesis that the deterioration of individual health is connected to the weakening of party identification. This result is in keeping with past studies (e.g. Converse [1976]; Dinas [2014]; Lupu [2015]) that have shown that the degree of party identification is not static but might change according to exogenous factors. 
Our findings also suggest that making a comeback from a period of poor health does not restore previous levels of party identification, at least not in the short-term. This might be explained by the fact that even when health improves, the negative effects of previous poor health cancel out the positive effects of current good health on partisan attachment. Thus, the negative impact of health on party identification seems to be rather resilient. This observation is compatible with the findings of Mattila and Rapeli (2018) who have demonstrated that declining health is associated with lower levels of political trust. Finally, to understand the association between health and party identification better, future studies should use such measures of health, which would differentiate between mental and physical health issues. As identification is a psychological phenomenon it is possible that identification reacts more strongly to mental than psychical health problems. 


\section{References}

ALLISON, PAUL. 2009. Fixed Effects Regression Models. London: Sage publications.

BARTELS, LARRY. 2000. Partisanship and voting behavior, 1952-1996. American Journal of Political Science 44 (1): 35-50.

BÖCKERMAN, PETRI and PEKKA ILMAKUNNAS. 2009. Unemployment and self-assessed health: Evidence from panel data. Health Economics 18 (2): 161-79.

BONNEAU, CHRIS and DAMON CANN. 2015. Party identification and vote choice in partisan and nonpartisan elections. Political Behavior 37 (1): 43-66.

BURDEN, C. BARRY and CASEY A. KLOFSTAD. 2005. Affect and cognition in party identification. Political Psychology 26 (6), 869-86.

CAMPBELL, ANGUS, GERALD GURIN and WARREN E. MILLER. 1954. The Voter Decides. Evanston: Row, Peterson and co.

CAMPBELL, ANGUS, PHILIP E. CONVERSE, WARREN E. MILLER, and DONALD E. STOKES. 1960. The American Voter. Chicago: University of Chicago Press.

COUTURE, JEROME and SANDRA BREUX. 2017.The differentiated effects of health on political participation. The European Journal of Public Health 27 (4): 599-604.

CONVERSE, E. PHILIP. 1976. The Dynamics of Party Support: Cohort Analysing Party Identification. Beverly Hills, CA: Sage.

DINAS, ELIAS. 2014. Does choice bring loyalty? Electoral participation and the development of party identification. American Journal of Political Science 58 (2): 449-65.

FINKEL, E. STEVEN and KARL-DIETER OPP. 1991. Party identification and participation in collective political action. The Journal of Politics 53 (2): 339-71.

GOERRES, ACHIM. 2007. Why are older people more likely to vote? The impact of ageing on electoral turnout in Europe. The British Journal of Politics and International Relations 9 (1): 90-121.

GOLLUST, E. SARAH and RAHN M. WENDY. 2015. The bodies politic: Chronic health conditions and voter turnout in the 2008 election. Journal of Health Politics, Policy and Law 40 (6): 1115-155.

GOREN, PAUL. 2005. Party identification and core political values. American Journal of Political Science 49 (4): 881-96.

GREEN, DONALD, BRADLEY PALMQUIST and ERIC SCHICKLER. 2002. Partisan Hearts and Minds: Political Parties and the Social Identity of Voters. Yale: Yale University Press. 
GREENE, STEVEN. 2002. The social-psychological measurement of partisanship. Political Behavior 24 (3): 171-97.

GREENE, STEVEN. 2004. Social identity theory and party identification. Social Science Quarterly 85 (1): $136-53$.

HASLAM, CATHERINE, TEGAN CRUWYS and ALEXANDER S. HASLAM. 2014. "The we's have It": Evidence for the distinctive benefits of group engagement in enhancing cognitive health in ageing. Social Science and Medicine 120: 57-66.

HOGG, A. MICHAEL and DOMINIC ABRAMS. 1988. Social Identifications: A Social Psychology of Intergroup Relations and Group Processes. London: Routledge.

JETTEN, JOLANDA, CATHERINE HASLAM and ALEXANDER S. HASLAM. 2012. The Social Cure: Identity, Health and Well-Being. Hove, UK: Psychology Press.

JETTEN, JOLANDA, et al. 2017. Advancing the social identity approach to health and well-being: progressing the social cure research agenda. European Journal of Social Psychology 47 (7): 789-802.

KELLY, CAROLINE. 1988. Intergroup differentiation in a political context. British Journal of Social Psychology 27: 319-32.

KRISHNA, ARADHNA and TATIANA SOKOLOVA. 2017. A Focus on partisanship: how it impacts voting behaviors and political attitudes. Journal of Consumer Psychology 27 (4): 537-45.

LEOPOLD, LILIYA and THOMAS LEOPOLD. 2018. Education and health across lives and cohorts: A study of cumulative advantage in Germany. Journal of Health and Social Behavior 59 (1): 94-112.

LEVENTHAL, HOWARD, ELLEN L. IDLER and ELAINE A. LEVENTHAL. 1999. The impact of chronic illness on the self-system. In Self, Social Identity, and Physical Health: Interdisciplinary Explorations, edited by Richard J. Contrada, and Richard D. Ashmore. Oxford University Press.

LUPU, NOAM. 2015. Party polarization and mass partisanship: A comparative perspective. Political Behaviour 37 (2): 331-56.

MATTILA, MIKKO, PETER SÖDERLUND, HANNA WASS and LAURI RAPELI. 2013. Healthy voting: The effect of self-reported health on turnout in 30 countries. Electoral Studies 32 (4): 886-91.

MATTILA, MIKKO, LAURI RAPELI, HANNA WASS and PETER SÖDERLUND. 2017. Health and Political Engagement. Routledge: London. 
MATTILA, MIKKO, LAURI RAPELI. 2018. Just sick of it? Health and political trust in Western Europe. European Journal of Political Research 57 (1): 116-34.

MILLER, E. WARREN and MERRILL J. SHANKS. 1996. The New American Voter. Cambridge, MA: Harvard University Press.

OJEDA, CHRISTOPHER. 2015. Depression and political participation. Social Science Quarterly 96 (5): 1226-243.

OJEDA, CHRISTOPHER and JULIANNA PACHECO. 2017. Health and voting in young adulthood. British Journal of Political Science. Epub ahead of print 13 July 2017. DOI:10.1017/S0007123417000151.

PRIOR, MARKUS. 2010. You've Either Got It or You Don't? The Stability of Political Interest Over the Life Cycle. Journal of Politics 72 (3): 747-66. DOI:10.1017/S0022381610000149. RAPELI, LAURI, MIKKO MATTILA and ACHILLEFS PAPAGEORGIOU. 2018. Breaking a habit: The impact of health on turnout and party choice. Party Politics. Epub ahead of print 10 January 2018. DOI: 10.1177/1354068817753060.

ROSCOE, D. DOUGLAS and NEIL D. CHRISTANSEN. 2001. Cognitive and Affective Components of Partisanship: An Examination of Intra-Attitudinal Structure and Political Behaviour. Paper, Annual meeting of the American Political Science Association. San Francisco.

SÖDERLUND, PETER and LAURI RAPELI. 2015. In sickness and in health: Personal health and political participation in the Nordic countries. Politics and the Life Sciences 34 (1): 28-43.

TAJFEL, HENRI and JOHN C. TURNER. 1986. The social identity theory of intergroup behaviour. In Psychology of Intergroup Relations, edited by Stephen Worchel and William G. Austin. Nelson-Hall Publishers.

WAGNER, G. GERT, JOACHIM R. FRICK and JÜRGEN SCHUPP. 2007. The German socioeconomic panel study (SOEP) -scope, evolution and enhancements. Schmollers Jahrbuch: Journal of Applied Social Studies 127 (1): 139-69. 
Table 1. The effect of health and party identification (PID). Linear regression, robust standard errors under the RE and FE.

\begin{tabular}{|c|c|c|c|c|}
\hline \multirow{3}{*}{$\begin{array}{l}\text { 'Bad' health after } \\
\text { 'good' (BHAG) }\end{array}$} & \multicolumn{2}{|c|}{ RE } & \multicolumn{2}{|c|}{$\mathrm{FE}$} \\
\hline & Model 1 & Model 2 & Model 1 & Model 2 \\
\hline & $\begin{array}{c}-.054 * * * \\
(.009)\end{array}$ & $\begin{array}{c}-.039 * * * \\
(.008)\end{array}$ & $\begin{array}{c}-.025 * * * \\
(.007)\end{array}$ & $\begin{array}{c}-.020 * * \\
(.007)\end{array}$ \\
\hline $\begin{array}{l}\text { 'Good' health after } \\
\text { 'bad' (GHAB) }\end{array}$ & $\begin{array}{c}-.033 * * * \\
(.009)\end{array}$ & $\begin{array}{c}-.029 * * \\
(.009)\end{array}$ & $\begin{array}{l}-.009 \\
(.007)\end{array}$ & $\begin{array}{l}-.012 \\
(.007)\end{array}$ \\
\hline $\begin{array}{l}\text { Health Becomes } \\
\text { 'good' at least once } \\
\text { (GHONCE) }\end{array}$ & $\begin{array}{l}.040 * \\
(.018)\end{array}$ & $\begin{array}{l}.041 * * \\
(.016)\end{array}$ & - & \\
\hline $\begin{array}{l}\text { Health Becomes } \\
\text { 'bad' at least once } \\
\text { (BHONCE) }\end{array}$ & $\begin{array}{l}-.025 \\
(.018)\end{array}$ & $\begin{array}{l}-.017 \\
(.016)\end{array}$ & - & \\
\hline $\begin{array}{l}\text { Always 'bad' health } \\
\text { (BHALW) }\end{array}$ & $\begin{array}{c}-.121 * * * \\
(.020)\end{array}$ & $\begin{array}{c}-.073 * * * \\
(.018)\end{array}$ & - & \\
\hline $\begin{array}{l}\text { Political Interest: } \\
\text { Not very interested }\end{array}$ & & $\begin{array}{c}.547 * * * \\
(.007)\end{array}$ & & $\begin{array}{c}.433 * * * \\
(.007)\end{array}$ \\
\hline Fairly interested & - & $\begin{array}{r}1.263 * * * \\
(.011)\end{array}$ & - & $\begin{array}{c}1.025^{* * *} \\
(.009)\end{array}$ \\
\hline Very interested & & $\begin{array}{r}1.677 * * * \\
(.016)\end{array}$ & & $\begin{array}{c}1.351^{* * *} \\
(.013)\end{array}$ \\
\hline $\begin{array}{l}\text { Gender: } \\
\text { Male }\end{array}$ & $\begin{array}{l}.300 * * * \\
(.012)\end{array}$ & $\begin{array}{l}.089 * * * \\
(.011)\end{array}$ & - & - \\
\hline $\begin{array}{l}\text { Education } \dagger \text { : } \\
\text { Intermediate }\end{array}$ & $\begin{array}{c}-.335 * * * \\
(.018)\end{array}$ & $\begin{array}{c}-.213 * * * \\
(.016)\end{array}$ & $\begin{array}{c}-.097 * * * \\
(.019)\end{array}$ & $\begin{array}{c}-.093 * * * \\
(.019)\end{array}$ \\
\hline Lower & & $-.373 * * *$ & & $-.076^{* *}$ \\
\hline
\end{tabular}




\begin{tabular}{|l|c|c|c|c|}
\hline & $\begin{array}{c}-.654 * * * \\
(.019)\end{array}$ & $(.017)$ & $\begin{array}{c}-.093 * * * \\
(.026)\end{array}$ & $(.026)$ \\
\hline Working status $\dagger \dagger$ & $-.023^{* *}$ & -.007 & $-.025 * * *$ & -.012 \\
Employed & $(.008)$ & $(.008)$ & $(.007)$ & $(.007)$ \\
\hline Age & $.026^{* * *}$ & $.015^{* * *}$ & -.017 & -.025 \\
& $(.002)$ & $(.002)$ & $(.014)$ & $(.014)$ \\
\hline Age & $-.000^{2} * *$ & -.000 & $-.000 * * *$ & -.000 \\
& $(.000)$ & $(.000)$ & $(.000)$ & $(.000)$ \\
\hline Year (dummies) & Yes & Yes & Yes & Yes \\
\hline $\mathrm{N}$ & 392,868 & 392,569 & 392,868 & 392,569 \\
\hline Rho & .54 & .48 & .67 & .64 \\
\hline
\end{tabular}

Notes: †Education (EDUC) has been coded according to Leopold and Leopold (2017): Lower (up to lower secondary vocational degree); Intermediate (up to higher secondary plus vocational training); Higher (lower and higher tertiary); $\dagger$ †Pensioners, voluntary military service, community service, etc. have been coded as missing; Reference category: 'Not interested in politics' (Political Interest); 'Female' (Gender); 'Higher' (Education); 'Unemployed' (Working status) $* * * \mathrm{p}<.001, * * \mathrm{p}<.01, * \mathrm{p}<.05$, alpha $=0.05$. 